\title{
Öğretmen Adaylarının Bilişsel Esneklik Düzeyleri ile Kültürel Zekâ Düzeyleri Arasındaki İlişkinin İncelenmesi
}

\author{
Akan Deniz YAZGAN \\ Çanakkale Onsekiz Mart Üniversitesi \\ akandeniz@hotmail.com \\ ORCID ID: 0000-0002-4607-6700
}

Araştırma Makalesi

Gelis Tarihi:01.10.2020

Revize Tarihi: 10.02.2021

DOI: $10.31592 /$ aeusbed. 803469

\section{Atıf Bilgisi}

Yazgan, A. D. (2021). Öğretmen adaylarının bilişsel esneklik düzeyleri ile kültürel zekâ düzeyleri arasındaki ilişkinin incelenmesi. Ahi Evran Üniversitesi Sosyal Bilimler Enstitüsü Dergisi, 7(1), 212-231.

\section{$\ddot{\mathbf{O Z Z}}$}

$\mathrm{Bu}$ araştırmanın amacı, bilişsel esnekliğin yordanmasında kültürel zekânın ne düzeyde katkıda bulunduğunu belirlemektir. Bilişsel esneklik, öğretmenlerin sahip olması beklenen ve yetiştirecekleri öğrencilere de kazandırmaları istenen yeterlikler arasında bulunmaktadır. Kültürel zekâ ise; kültürel bilgi, farkındalık uygulamaları ve davranışsal beceri birikimine dayanan çok boyutlu bir yetkinlik olarak belirmektedir. Çalışma grubunu, Çanakkale Onsekiz Mart Üniversitesi (ÇOMÜ) Eğitim Fakültesi'nde öğrenim gören 260 öğretmen adayı oluşturmaktadır. Araştırmada veri toplamak amacıyla Dennis ve Vander Wal (2010) tarafindan geliştirilip; Sapmaz ve Doğan (2013) tarafindan Türkçe'ye uyarlanan "Bilişsel Esneklik Envanteri (BEE)" ve Ang vd. (2007) geliştirilip, Türkçe'ye uyarlaması İlhan ve Çetin (2014) tarafindan yapılan "Kültürel Zekâ Ölçeği” kullanılmıştır. Araştırmada elde edilen verilerin analizinde betimsel istatistikler (frekans, yüzde, aritmetik ortalama ve standart sapma) ve çoklu regresyon analizi kullanılmıştır. Araştırmada ulaşılan bulgulara göre, öğretmen adaylarının bilişsel esneklik ve kültürel zekâ düzeyleri yüksektir. Öğretmen adaylarının üst biliş ve motivasyon puanları bilişsel esneklik düzeyini olumlu yönde etkilerken, biliş ve davranış puanları etkilememektedir. Ayrıca öğretmen adaylarının kültürel zekâ toplam puanları, bilişsel esneklik düzeylerini anlamlı olarak yordamaktadır.

Anahtar Kelimeler: Bilişsel esneklik, kültürel zekâ, öğretmen yetiştirme, öğretmen adayları.

\section{Investigation of the Relationship Between Pre-service Teachers' Cognitive Flexibility Levels and Cultural Intelligence Levels}

\begin{abstract}
The purpose of this study is to determine to what extent cultural intelligence contributes to the prediction of cognitive flexibility. The working group consists of 260 teacher candidates studying at Çanakkale Onsekiz Mart University Faculty of Education. "The Cognitive Flexibility Inventory (BEE)", developed by Dennis and Vander Wal (2010) and adapted into Turkish by Sapmaz and Doğan (2013); the "Cultural Intelligence Scale", developed by Ang et al. (2007) and adapted to Turkish by İlhan and Çetin (2014) was used to collect data in the study. Descriptive statistics (frequency, percentage, arithmetic mean and standard deviation) and multiple regression analysis were used in the analysis of the data obtained in the study. According to the findings of the study, the cognitive flexibility and cultural intelligence levels of the teacher candidates are high. While the metacognition and motivation scores of the teacher candidates positively affect the cognitive flexibility level, they do not affect the cognition and behavior scores. In addition, preservice teachers' cultural intelligence total scores significantly predicted their cognitive flexibility levels.
\end{abstract}

Keywords: Cognitive flexibility, cultural intelligence, teacher training, teacher candidates.

\section{Giriş}

İnsanoğlu dünyaya gözlerini açtığ 1 andan itibaren sürekli olarak daha önce hiç karşılaşmadı̆̆ 1 durumlarla karşılaşmakta ve bu yeni durumlara karşı bir davranış stratejisi belirlemek zorunda kalmaktadır. Bireyler bu durumlarla ilgili davranış stratejilerini belirlemeden önce, seçeneklerinin farkına vararak o durumla ilgili en doğru davranışın hangisi olduğuna karar verme süreci yaşamaktadır (Koşar, 2019). Birey davranışlarını yapmaya karar vermeden önce, farklı yolları bilmelidir. Belirli bir durumla ilgili yol haritası olan birey en doğru davranışı gören bireye göre daha fazla düşünüyor ve bilişsel çaba harcıyor demektir. Bu sayede, birey aynı anda farklı çözüm yolları geliştirebilir (Bilgin, 2009). 
Bireyin genetik özellikleri ve kültürel geçmişi onun herhangi bir durumla ilgili nasıl davranacağı konusunda belirleyici olmaktadır. Yani herhangi bir durum karşısında her birey farklı bir şekilde davranabilmektedir (Sapmaz ve Doğan, 2013). Bireyler toplum içerisnde farklı sorunlarla karşılaşmakta ve bunları öğrenmiş olduğu becerilerle ya da bilişsel düşünce yapılarını kullanarak iki farklı şekilde çözmektedir (Peker ve Çukadar, 2016). Daha fazla bilişsel esneklik, çocuklukta daha iyi okuma becerileri, olumsuz yaşam olaylarına karşı daha yüksek direnç ve yetişkinlikte stres, yetişkinlikte daha yüksek yaratıcılık seviyeleri ve yaşlı bireylerde daha iyi yaşam kalitesi gibi yaşam boyu olumlu sonuçlarla ilişsilidir (Dajani ve Uddin, 2015). Bilişsel açıdan esnek bireylerin, alternatiflerin farkında, yeni ve zor durumlarla güçlü bir şekilde baş edebilecek, farklı düşünce ve fikirler üretebilecek ve yeni durumlara uyabilecek düzeyde olması beklenmektedir (Altunkol, 2011). Düşünce modları arasında geçiş yapma ve aynı anda birden çok kavramı dikkate alma yeteneği olarak ifade edilen bilişsel esneklik, öğrenmenin, dil gelişiminin, aritmetik becerilerin, kişilerarası iletişimin, iletişim öz yeterliğinin, girişkenliğin, yanıt vermenin, çoklu görev yapmanın, işbirliği yapma isteğinin, liderliğin, karar vermenin ve problem çözmenin hayati bir bileșeni olarak kabul edilebilir (Kercood, Lineweaver, Frank ve Fromm, 2017).

Bilişsel esneklik, öğretmenlerin sahip olması beklenen ve yetiştirecekleri öğrencilere de kazandırmaları istenen yeterlikler arasında bulunmaktadır (Kılıç ve Demir, 2012). Bilişsel esnekliğe sahip bireylerin; uyumlu ve olumlu tutumlar sergileme, dikkatli, çözümleyici ve değişikliklere açık olma, eş zamanlı olarak birden fazla görevi üstlenme, ani durumlar karşısında elindeki ipuçlarından yararlanma becerisine sahip olma gibi özellikleri ile öğretmenlerin sahip olması beklenen kendine güvenli bir tutum sergileme, arkadaşça davranma, öğrencileri birey olarak görme ve nezaketli, saygıll davranma, etkinliklere aktif olarak katılımlarını sağlama gibi özelliklerinin birbiri ile örtüştüğü görülmektedir (Kaptanbaş Gürbüz ve Sezgin Nartgün, 2018). Yaşar Ekici ve Balcı'nın (2019) ifadesiyle, öğretmenlik mesleği, doğrudan insanlarla etkileşimi içeren bir meslek olma özelliğiyle farklı insanlarla, mizaçlarla ve davranışlarla karşılaşma ihtimalinin en yüksek olduğu mesleklerdendir. Bundan dolayı, ögretmenlerin bu gibi farklı durumlara uyum sağlayabilmeleri ve seçenekler üretebilmeleri açısından bilişsel esneklik düzeylerinin yüksek olması önem taşımaktadır..

Çalışmanın diğer boyutunu kültürel zekâ oluşturmaktadır. Kültürel zekâ, 2000'li yılların başında tanitılan görece olarak yeni bir kavramdır (Harrison ve Brower, 2011) ve herkesin sahip olduğu bir beceri olmasa da günümüz küresel toplumunda önemli bir beceri olarak kabul edilmektedir (Nilsson ve Truong, 2012). Alexandra, Ehrhart ve Randel'in (2021) ifadesiyle, kültürler aras1 bağlamlarda adaptasyon ve etkililikteki bireysel farklılıklar, işyerleri küreselleştikçe ve kültürel olarak daha farklı hale geldikçe akademisyenler ve uygulayıcılar arasında artan bir ilgi kazanmıştır. Dangmei'nin (2016) ifadesiyle, küreselleşme, farklı bireylerin bir araya gelmesine ve farklı kültürlerden bireylerin birbirleriyle etkileşime girmesine neden olmaktadır. Bu farklılıklar, yanlış anlaşılmalara neden olabilecek ve ayrıca etkisiz etkileşimlere ve örgütsel zararlara neden olabilecek kültürel engellere yol açabilmektedir.

Günümüzde, zekânın sadece sınıf içinde kalmadığı, daha büyük bir resmin parçası olduğu ve sosyal yönün (sosyal zekâ), duygusal yönün (duygusal zekâ) ve pratik zekânın yarattığı gerçek bir dünyaya ait olduğu evrensel olarak kabul edilmektedir (Ziyatdinova, 2017). Kültürel zekâ fikrinin arkasındaki itici soru şudur: Neden bazı insanlar görüşlerini ve davranışlarını kültürler arası olarak kolayca ve etkili bir şekilde uyarlarlar? (Van Dyne, Ang ve Livermore, 2010). Duygusal zekâsı yüksek bir kişi, bizi neyin insan yaptığını ve aynı zamanda her birimizi birbirimizden farklı kılan şeyleri kavrar. Kültürel zekâsı yüksek bir kişi, bir kişinin veya grubun davranışından bir şekilde tüm insanlar ve tüm gruplar için geçerli olan özellikleri, bu kişiye veya bu gruba özgü olanları ve ne evrensel ne de kendine özgü olanları anlayabilir. Bu iki kutup arasında uzanan uçsuz bucaksız alan kültürdür (Earley ve Mosakowski, 2004). Bununla birlikte, önceki araştırmalardan elde edilen kanıtlar, kültürel zekânın, genel zekâ ile ilişkili olmadığını, ancak duygusal zekâ ile güçlü bir şekilde ilişkili olduğunu ortaya çıkarmıştır (Li, 2020).

Bu kapsamda, öğretmen adaylarının kültürel zekâ düzeylerinin, bilişsel esneklik düzeylerini yordayıp yordamadığı araştırmanın temel problemini oluşturmaktadır. Araştırmada ortaya çıkan 
bulguların eğitim politikalarına yön veren karar vericiler, konuya farklı açılardan ve bilimsel disiplinlerden bakmaya çalışan akademisyenler ve öğretim süreçlerini mükemmelleştirmeye çalışan öğretmenler için faydalı olacağı söylenebilir.

Araştırma problemini çözümlemek için aşağıdaki araştırma sorularına cevap aranmaktadır:

1. Öğretmen adaylarının bilişsel esneklik düzeyleri

a. Alternatif

b. Kontrol boyutlarına göre nedir?

2. Öğretmen adaylarının kültürel zekâ düzeyleri,
a. Üstbiliş
b. Biliș
c. Motivasyon
d. Davranış boyutlarına göre nedir?

3. Öğretmen adaylarının kültürel zekâ düzeyleri toplam bilişsel esneklik puanlarına göre yordanmakta midir?

\section{Bilişsel Esneklik}

Bireylerin otomatik tepkilerini engelleyen ve mevcut durumu bağımsız olarak yönetme kapasitesi olarak görülen bilişsel esneklik, nöropsikolojik olarak yürütücü işlev olarak adlandırılan daha geniş bir yapının alt boyutu olarak görülmektedir (Gündüz, 2013). Yürütücü işlev, işlevleri başlatmak ve kontrol etmek için kullanılan genel bir terimdir ve genellikle insan beyninin frontal (ön) lob yapıları ile ilişkilidir (Memari, Ziaee, Shayestehfar, Ghanouni, Mansournia ve Moshayedi, 2013). Yürütücü işlevler, amaca yönelik eylemleri gerçekleştirmede yer alan çalışma belleği, ketleme ve bilişsel esneklik dâhil olmak üzere bilişsel becerileri tanımlar (Blair ve Peters, 2003).

Esneklik, insan bilişinin ve zekânın ayırt edici bir özelliği olarak kabul edilir ve zekâ ile yaratıcılığın ilk modellerinden bu yana bilinir (Ionescu, 2012). Bilişsel esneklik, bakış açılarını mekânsal veya kişilerarası olarak değiştirmek için kavramsal temsiller arasında geçiş yapma yeteneği ve olguları farklı bakış açılarından görebilme olarak ifade edilmektedir (Davidson, Amso, Anderson ve Diamond, 2006; Diamond, 2013; Knudsen, Lopez ve Archibald, 2018; Martin ve Anderson, 1998; Rathgeb-Schnierer ve Green, 2017; Stevens, 2009). Bu süreçler, bireyin olumsuz bir otomatik düşünceyi tanımlaması, bu düşünceyle çelişen kanıtlar üretmesi ve ardından durumu yorumlamanın daha uyarlanabilir veya yardımcı bir yolunu üretmesi gereken bilişsel yeniden yapılandırmanın başarılı bir şekilde uygulanması için önemli görünmektedir (Johnco, Wuthrich ve Rapee, 2014).

Martin ve Rubin (1995) aşă̆ıdaki değişkenleri bilişsel esnekliğin nitelikleri olarak tanımlamışlardır:

- Seçenekler ve alternatifler konusunda farkındalık,

- Durumlara uyum sağlama isteği,

- Farklı durumların gereklerini karşılamada kişinin kendi esnek olma yeteneğine olan inancı.

Seçeneklerden haberdar olmak, bireylerin alternatif açıklamalar, hipotezler veya çözümler geliştirmesine olanak tanır (Ör: Zihinsel modeller), ve sahip oldukları seçenekler ne kadar fazlaysa, duruma en uygun olanı öngörebilir ve seçebilirler (Darabi, Hemphill, Nelson, Boulware ve Liang, 2010). Tüm organizmalar, hayatta kalmak için dinamik çevresel gerekliliklere uyum sağlamalıdır ve düşünce ve/veya tepki modellerini değiştirme yeteneği, bilişsel esnekliği karakterize eder (Powell ve Ragozzino, 2017). Bilişsel olarak esnek bireyler hızlıdır, sorumluluk sahibidir ve deneyimlediklerini anlamlandırabilirler (Çelikkaleli, 2014a). Ayrıca akademik, sosyal ve duygusal yeterlilik inançları daha yüksektir (Çelikkaleli, 2014b). Kolburan, Eken ve Akdeniz'in (2019) vurguladığı gibi, yapılan araştırmalarda bilişsel esnekliğin, daha yüksek hoşgörü, kavga ve saldırganlığa eğilimin az olması ve sözel saldırganlık; sosyal becerilerde yetkinlik inancı ve problem çözme becerisi; depresyon; bilişsel yetenekler; dil; aritmetik beceriler ve iş birliğine dayalı karar verme ile ilişkili olduğu ortaya konulmuştur. 
Chieu'ye (2007) göre, bilişsel esneklik sıklıkla yapılandırmacı yazarlar tarafından dile getirilir ve bilişsel esnekliğin altında yatan pedagojik ilkeler, yapılandırmacılığın temel özelliklerini yansıtır. Cheng ve Koszalka'nın (2016) altını çizdiği gibi; Bilişsel Esneklik Teorisi, öğretim tasarımcıları ve deneyimli eğitimcilere, öğrencilerin kötü yapılandırılmış problemler için derin bilgi (ve uygulama) geliştirmede daha etkili bir şekilde ilgisini çekebilecek öğrenme ortamları ve senaryoları geliştirmek için bir çerçeve sağlar. Spiro, Coulson, Feltovich ve Anderson (1988, s. 641) kötü yapılandırılmışlığı şu anlama gelecek şekilde tanımlar: "Birçok kavram (bağlamsal olarak etkileşimde bulunan) tipik bilgi uygulaması durumunda geçerlidir ve kombinasyon kaliplar ayn nominal tipteki vaka uygulamalarında tutarsızdır”. Bu tür öğrenme ortamları oluşturmanın kilit noktaları şunları içerir: 1 . Çoklu bilgi temsilini kullanmak; 2. Soyut kavramlarla bağlantılı birden çok durum kullanmak; 3. Vakalar arasında yeniden düzenleme, ayrıştırma ve bağlantı kurma ve 4. Alan karmaşıklığına erken giriş (Cheng ve Koszalka, 2016).

Spiro, Feltovich, Jacobson ve Coulson (1992), atıl bilginin o kadar katı olduğunu bulmuşlardır ki, bu şartlar altında öğrenciler bilgilerini yalnızca tanıdık bir ortamdaki benzer problemlere uygulayabilir, ancak farklı bağlamlar altındaki farklı problemlere uygulayamazlar. Coulson, Feltovich ve Spiro (1997) ve Feltovich, Spiro, Coulson ve Feltovich (1996), öğretmenlerin öğrencileri gerçek durumlardaki problemlerin çeşitli yönlerini ve çoklu bakış açılarını ele almaya teşvik etmelerini tavsiye ederler; birden çok pedagojik modelin, birden çok metafor ve analojinin ve ayn bilginin birden çok yorumunun kullanılmasını savunurlar. Bilişsel esneklik, bir öğrencinin parçalara ayrılmış öğretim eylemini, tutarlı bir zihinsel modele entegre etme yeteneğini etkileyecek bireysel bir farklılık gibi görünmektedir (Darabi, Hemphill, Nelson, Boulware ve Liang, 2010). Bireylerdeki öğrenme güçlüklerinden kurtulmak için, öğrenme süreçlerinde onlara daha fazla bilişsel esneklik aşılamak gerekir (Spiro, Vispoel, Schmitz, Samarapungavan ve Boerger, 1987).

\section{Kültürel Zekâ}

Bir toplumun yaşam tarzı olarak nitelendirilen kültür, toplumdan edinilen bilgi, inanç, sanat, yasalar, gelenekler, alışkanlıklar ve yeteneklerden oluşan karmaşık bir bütündür (Göl ve Erkin, 2019). Kültür, belirli bir toplumda bireylerin davranışlarının tüm yönlerini etkilemektedir (De Mooij, 2011). Farklı ulusal kültürlere maruz kalma, bir insanın o kültürün ürünlerine, normlarına, değerlerine ve varsayımlarına aşina olmasını sağlar (Crowne, 2008). On yıllardır, farklı disiplinlerden (ör: psikoloji, sosyoloji, yönetim, eğitim) araştırmacılar, belirli bireylerin neden diğerlerine göre küresel veya kültürel açıdan farklı durumlara daha zahmetsiz ve etkili bir şekilde uyum sağlayabileceklerini belirlemeye çalıştılar (Azevedo ve Shane, 2019).

Bireylerin kültürel açıdan farklı bir çevreyi anlama ve buna uyum sağlama kapasitelerinin önemli bileşenlerinden biri kültürel zekâdır. Kültürel zekâ, bireyin kültürel çeşitlilik ile tanımlanabilen durumlarda etkin bir şekilde iş görebilme kapasitesi olarak tanımlanmıştır (Ang ve diğerleri, 2007; Deng ve Gibson, 2008; Presbitero ve Quita, 2017). Küreselleşmenin farklı iş kollarına yansımaları, gözlemcilerin çalışanlardaki kültürel zekâyı arttırma ihtiyacına dönük dikkatlerini yoğunlaştırmıştır (Alon ve Higgins, 2005). Küreselleşme bağlamında kültürel çeşitliliği incelemek ve anlamak; güncel ve aynı zamanda çok da karmaşık bir sorundur çünkü küreselleşme çok kültürlü etkileşimleri yoğunlaştırmakta, aynı zamanda gerginlik ve çatışmalar da yaratmaktadır (Brancu, Munteanu ve Golet, 2016).

Farklı zekâ biçimleri, son zamanlarda sayısız kuramsal tartışma ve ampirik araştırmanın konusu olmuştur (Petrovic, 2011). Psikoloji bilimi açısından bakıldığında zekâ; akıl yürütme yeteneği, merak, uyum, dikkat, problem çözme yeteneği, hafıza, yargılama veya bizi farklı kılan, karakterize eden belli yeteneklerin gösterilmesiyle ilgilidir ve aynı zamanda örgütsel, analitik ve görsel becerilerin gelişiminde önemli rol oynar (Pena-Acuna ve Pisonero, 2017). Ayrıca zekâya olan ilginin artışı, bir kişinin kültürlerarası ortamlardaki kültürle ilişkili davranışları ayırt etme yeteneğini ölçebilecek bir zekâ konseptinin kavramsallaştırılmasını teşvik etti (Malek ve Budhwar, 2013). Kültürel zekâ; kültürel bilgi, farkındalık uygulamaları ve davranışsal beceri birikimine dayanan çok boyutlu bir yetkinliktir (Lorenz, Ramsey ve Richey, 2018; Thomas ve Inkson, 2004; Triandis, 2006). Azevedo ve Shane'e 
(2019) göre, kültürel zekânın öncülleri; deneyime açıklık, dışa dönüklük ve vicdanlılık gibi kişilik özellikleri, esneklik/açıklık, duygusal esneklik, algısal keskinlik ve kişisel özerklik gibi kültürlerarası özellikler, iş gezileri, diş atamalar gibi işle ilgili deneyimler ve uluslararası veya kişisel amaçlı eğitimler gibi işle ilgili olmayan deneyimler de dahil olmak üzere uluslararası deneyimler (Ör: yurtdışı öğrenim deneyimi) olarak ifade edilmektedir. doğurabilir:

Kültürel zekânın sonucu olarak kültürlerarası etkileşimin başarılı olması şu sonuçları

- Bireyde iyi uyum sağlayabilirlik (zevk ve iyi oluş duygularında kendini gösterir),

- Diğer kültür üyeleri ile iyi ilişkiler geliştirmek ve sürdürmek

- Etkileşim hedeflerine ulaşmada başarı (Petrovic, 2011).

Thomas ve diğerlerine (2015) göre, kültürel zekâ duygusal zekâyla orta düzeyde ilişkili fakat duygusal zekâdan farklı bir zekâ türüdür. Kültürel zekâ aynı zamanda kültür şokuyla etkileşime girerek, onun psikolojik ve sosyo-kültürel uyuma olan etkisini azaltabilir (Presbitero, 2016).

Ang ve Van Dyne'e (2015) göre, kavram olarak kültürel zekâ, metabiliş, biliş ve motivasyon bileşenlerinin yanı sıra, çok kültürlü ilişkiler bağlamından dolayı birinin davranışına aktarılan etkileri ile vurgulanan, ruhsal, entelektüel yetenekleri analiz etme ve değerlendirme çabasıdır. Metabilişsel kültürel zekâ, başka kültürlerle ilgili bilgi ve bilgileri edinme ve anlama, bir kişinin kendi çokkültürlü deneyimini aydınlatma şeklini yansıtan zihinsel kapasiteyi yeniden üretir. Metabilişsel kültürel zekânın, çokkültürlü bir toplantı yaklaşımıyla ilgili stratejiler oluşturmak, ilk hipotez tarafsızlığının analiz ve değerlendirilmesine katkıda bulunmak ve stratejinin gerçek koşullara göre değiştirilmesi üzerinde büyük bir etkisi vardır. Bilişsel kültürel zekâ, diğer kültürlerden gelen normlar, uygulamalar, geleneklerle ilgili kişisel bilgi düzeyini ifade eder ve bireyin kendi kültürüyle diğer kültürler arasındaki farklılıkların/benzerliklerin anlaşılmasına katkıda bulunur. Motivasyonel kültürel zekâ, diğer kültürlerin belli özelliklerinin anlaşılmasıyla ilgili olarak bir kişinin gösterdiği ilgiyi yansıtır ve kültürlerarası ilişkiler düzeyiyle ilgili kişisel güvenin artmasına belirleyici bir katkısı vardır. Davranışsal kültürel zekâ, diğer kültürleri oluşturan, belirli sözel ve sözel olmayan davranışsal öğelere kişisel uyarlanma derecesini tanımlar. Bu tür bir kültürel zekâ seviyesinin yüksek olması, çokkültürlü bağlama uygun, hızlı bir reaksiyon sağlar (Ang ve Van Dyne, 2015). Kültürel zekâ çalışmaları, yalnızca performans değil aynı zamanda doyum üzerinde de etkilerin gözlendiği sonuçlar üretmektedir (Henderson, Stackman ve Lindekilde, 2018).

\section{Yöntem}

\section{Araştırma Deseni}

Araştırmanın problem ve çözümünün açık bir şekilde ortaya koyulabilmesi için ilk olarak konuyla ilgili bilimsel alanyazın incelenmiştir. Bilimsel alanyazın taranması sürecinde araştırma konusuna benzer nitelikte daha önce yapılmış araştırmalar incelenmiştir. Bu araştırmalardan yola çıkılarak, araştırma problemi şekillendirilmeye çalışılmıştır. Bir sonraki aşamada ise, incelenen benzer nitelikteki araştırmaların amaçları, yöntemleri, sonuçları ve yararlandıkları kaynaklar incelenerek araştırmada nasıl bir yöntem izleneceği ve hangi kaynaklara ulaşılabileceği belirlenmiştir.

\section{Araștırma Modeli}

Çalışma nicel bir araştırmadır ve ilişkisel (korelasyonel) araştırma olarak tasarlanmıştır. Nicel araştırma, olguları açıklamak için istatistiğe dayalı matematiksel yöntemler kullanarak toplanan verilerin analizine dayanır (Aliaga ve Anderson, 2002). Creswell'in (2011) ifadesiyle, korelasyonel araştırma tasarımlarında, araştırmacılar, iki veya daha fazla değişken veya puan seti arasındaki ilişki derecesini tanımlamak ve ölçmek için ilişkisel istatistiklere başvurur. İlişkisel bir çalışmada, incelenen iki değişken temelde eşdeğerdir. Bununla birlikte, ilişsisel çalışmalar genellikle bir değişkeni yordayıcı değişken olarak ve ikinci değişkeni ölçüt değişkeni olarak tanımlar. Bu çalışmada da, ilk 
önce kültürel zekâ ve bilişsel esneklik değişkenleri arasındaki ilişkiye bakılmış ve ilişkinin anlamlı olması doğrultusunda yordayıcı değişken olarak belirlenen kültürel zekâ düzeyinin, ölçüt değişkeni olarak belirlenen bilişsel esneklik düzeyi üzerinde etkisi olup olmadığ incelenmiş̧tir.

\section{Evren ve Örneklem}

Araştırma evrenini ÇOMÜ Eğitim Fakültesi'nde öğrenim gören öğretmen adayları oluşturmaktadır. Örneklem seçiminde uygun örnekleme (convenience sampling) yöntemi tercih edilmiştir. Bu örnekleme yöntemiyle araştırmacılar, araştırmanın doğasına uygun ve katılıma istekli bireyleri çalışmaya dahil ederler. Bu kapsamda, araştırmacılar "kimin uygun olduğu, kimin ortam hakkında özel bir bilgiye sahip olduğu ve kimin bu rolde hizmet vermeye istekli olduğu" temelinde kararlar alırlar (Liamputtong, 2016). Örneklem büyüklüğü 260 katılımcıdan oluşmaktadır. Örneklem, İngilizce Öğretmenliği, Fen Bilgisi Öğretmenliği, Sosyal Bilgiler Öğretmenliği, Japonca Öğretmenliği, Türkçe Öğretmenliği bölümlerinde örgün öğretim gören bireylerden oluşmaktadır.

Tablo 1

\begin{tabular}{llcc} 
Örnekleme İlişkin Betimsel Istatistikler & & \\
\hline \multirow{3}{*}{ Cinsiyet } & & $\mathrm{N}$ & $\%$ \\
& Kadın & 187 & 71.9 \\
& Erkek & 73 & 28.1 \\
& Toplam & 100 & 100 \\
& İngilizce Öğretmenliği & 28 & 10.8 \\
\multirow{4}{*}{ Bölüm } & Fen Bilgisi Öğr. & 83 & 31.9 \\
& Sosyal Bilgiler Öğg. & 46 & 17.7 \\
& Japonca Öğr. & 29 & 11.2 \\
& Türkçe Öğr. & 74 & 28.5 \\
& Toplam & 100 & 100 \\
\hline
\end{tabular}

Tablo.1'de görüldüğü üzere çalışmaya toplam 260 öğretmen adayı katılmıştır. Çalışmaya katılan öğretmen adaylarının \%75.2'si (357 kişi) kadın, \%24.8'ini (118 kişi) erkek öğrenciler oluşturmaktadır. Örnekleme alınan öğretmen adaylarının en fazla Fen Bilgisi Öğretmenliği (\%31.9), en az ise İngilizce Öğretmenliği (\%10.8) bölümlerinde öğrenim gördükleri anlaşılmıştır.

\section{Veri Toplama Araçları}

Çalışmanın bu aşamasında, veri toplama sürecinde kullanılan ölçme araçlarının özellikleri açıklanmış; güvenirlik çalışmaları ve sonuçları belirtilmiştir. Çalışmanın veri toplama sürecinde Sapmaz ve Doğan (2013) tarafindan geliştirilen Bilişsel Esneklik Envanteri ile İlhan ve Çetin (2014) tarafından Türkçe'ye uyarlanan Kültürel Zekâ Ölçeği kullanılmıştır. Alt başlıklarda her bir ölçme aracı ayrı ayrı ele alınarak açıklanmaktadır.

\section{Bilişsel Esneklik Envanteri}

Bilişsel Esneklik Envanteri-BEE (Cognitive Flexibility Inventory-CFI) Dennis ve Vander Wal (2010) tarafından geliştirilmiş; Sapmaz ve Doğan (2013) tarafindan Türkçe'ye uyarlanarak geçerlik ve güvenirlik çalışmaları yapılmıştır. Ölçek "alternatifler" ve "kontrol" olmak üzere iki boyuttan oluşmaktadır. "Alternatifler" boyutu 13 maddeden oluşmakta ve bireyin zor durumlara alternatif çözümler bulunabileceğine ya da yaşam durumları ve insan davranışlarına yönelik olarak alternatif açıklamaların olabileceğine yönelik maddelerden oluşmaktadır. "Kontrol" alt boyutu ise 7 maddeden oluşmakta ve zor durumların kontrol edilebileceğine yönelik ifadelerden oluşmaktadır. Envanterde, puanların yüksekliği bilişsel esnekliğin yüksek olduğuna işaret etmektedir. 
Sapmaz ve Doğan (2013) tarafindan Türkçe'ye çevrilen envanterde, toplam puan açısından özgün form ile Türkçe form arasında .97 korelasyon elde edilmiştir. Ölçeğin Türkçe' ye uyarlama çalışmasında cronbach alpha güvenirlik katsayıları ölçeğin tümü için .90; "alternatifler" alt boyutu için .90 ve "kontrol" alt boyutu için .84 olarak bulunmuştur (Sapmaz ve Doğan, 2013). Bu çalışmada gerçekleştirilen güvenirlik sonuçları (croanbach alpha - iç tutarlık katsayısı) şu şekildedir: "alternatifler" alt boyutu için güvenirlik katsayısı .88, "kontrol" alt boyutu için güvenirlik katsayısı .84 , ölçeğin toplamı için güvenirlik katsayısı ise .89 'dur. Bu değerler kapsamında, ölçme aracı güvenilirdir.

Bilişsel Esneklik Envanterinin Değerlendirilmesi: BEE, 5' li likert tipinde bir ölçektir. "Kesinlikle katılmıyorum" (1), "Katılmıyorum" (2), "Ne kat1lıyorum ne katılmiyorum" (3), "Katılıyorum" (4), "Kesinlikle katılıyorum" (5) şeklinde puanlanmaktır. Ölçeğin 2, 4, 7, 9, 11, 17. maddeleri tersten kodlanmaktadır. Ölçekten toplam bilişsel esneklik puanı, "alternatifler" alt boyutu puanı ve "kontrol" alt boyutu puanı olmak üzere üç farklı türde puan alınabilmektedir. Bilişsel esnekliği yüksek bireylerin özellikleri, kendi başına karar alabilme becerisi ve benlik saygısı yüksek, olaylara farklı açılardan bakabilen, içten denetimli, depresif düzeyi daha düşük ve iyimser olarak siralanabilir (Sapmaz ve Doğan, 2013).

\section{Kültürel Zekâ Ölçeği}

Kültürel Zekâ Ölçeği Ang ve diğerleri (2007) tarafından bireylerin kültürel zekâlarını ortaya koymak amacıyla geliştirilmiş ve Türkçe'ye uyarlaması, geçerlik ve güvenirlik çalışmaları İlhan ve Çetin (2014) tarafından yapılmıştır. 5'li likert tipi bir derecelendirmeye sahip olan ölçekte 20 madde bulunmaktadır. Ölçek; Üst Biliş, Biliş, Motivasyon ve Davranış olarak adlandırılan 4 alt boyuttan oluşmaktadır. Bireylerin sahip olduğu kültürel bilgiler üzerinde kontrol sahibi olup olmamasını ve sahip olduğu kültürel bilgileri anlamada kullandığı zihinsel süreçleri yansitan üst biliş alt boyutunda 4 madde bulunmaktadır. Örnek Madde: "Kültürlerarası etkileşimlerde kullandiğım kültürel bilgimin farkındayım." Bireylerin farklı kültürler hakkında sahip olduğu bilgileri yansıtan biliş alt boyutunda 6 madde bulunmaktadır. Örnek Madde: "Diğer kültürlerin dini inançlarını ve kültürel değerlerini bilirim.”. Bireylerin farklı kültürlerden insanlarla etkileşime girme konusundaki ilgisini ve bu konudaki öz yeterlik inancını yansitan motivasyon alt boyutunda 5 madde bulunmaktadır. Örnek Madde: "Farklı kültürden insanlarla etkileşim kurmaktan zevk alırım.". Bireylerin farklı kültürel geçmişe sahip insanlarla karşılaştığında uygun sözel ya da sözel olmayan davranışları sergileyebilme yeteneğini yansıtan davranış alt boyutunda 5 madde bulunmaktadır. Örnek Madde: "Konuşma hızımı kültürlerarası etkileşimin gereklerine göre değiştirebilirim."

Ölçekte ters madde bulunmamakta; yüksek puan yüksek kültürel zekâ düzeyini temsil etmektedir. Kültürel Zekâ Ölçeği'nden yüksek puan alan bireylerin farklı kültürlerden insanlarla etkileşim halindeyken uygun davranışları sergileyebilme, kültürler arası etkileşimden hoşlanma, farklı kültürlerle etkileşime girme konusunda kendine güvenme, farklı kültürler hakkında bilgi edinme ve edindiği bilgileri etkileşimde bulunduğu kültürün gereklerine göre ayarlayabilme becerilerinin gelişmiş olduğu ifade edilmektedir. Kültürel Zekâ Ölçeği'nden düşük puan alan bireylerin ise, farklı kültürler hakkında bilgi edinme, kültürler arası farkl1lıklara uyum sağlama ve farklı kültürlerle etkileşime girme konularında isteksiz oldukları söylenebilir (Yaşar Ekici, 2017). İlhan ve Çetin (2014)'in çalışmalarında ölçme aracının güvenirliği için iç tutarlık katsayısına bakılmıştır. Cronbach alfa katsayıları sırasıyla, .77 (üstbiliş), .79 (biliş), .75 (motivasyon) ve .71 (davranış) olup, ölçeğin tümüne yönelik güvenirlik katsayısı $.85^{\prime}$ tir. Mevcut çalışmanın güvenirlik incelemesi için de iç tutarlık katsayısına bakılmıştır. Üstbiliş boyutu için güvenilrlik katsayısı .80 , biliş boyutu için güvenirlik katsayısı .79 , motivasyon boyutunun .81 , davranış boyutunun .69 , toplam ölçeğin .86 'dır. Ölçme aracı güvenilirdir.

\section{Verilerin Toplanması ve Analizi}

Nicel verilerin yorumlanmasında, farkın önemliliği için $p=0.5$ düzeyi aranmıştır. Birinci ve ikinci araştırma soruları için betimsel istatistik teknikleri kullanılmış; bu kapsamda frekans, yüzde, 
aritmetik ortalama ve standart sapma değerleri hesaplanmıştır. Üçüncü araştırma sorusu için çoklu regresyon analizi gerçekleştirilmiştir.

Betimsel analizlerde katılımcıların düzeylerini belirlemek için puanlara yönelik şu aralıklar dikkate alınmaktadır: 1.00-1.49: Çok düşük düzey; 1.50-2.49: Düşük düzey; 2.50-3.49: Orta düzey; 3.50-4.49: Yüksek düzey; 4.50-5.00: Çok yüksek düzey.

\section{Araştırma Etiği}

Etik onay ve yazılı izin Çanakkale Onsekiz Mart Üniversitesi Bilimsel Araştırmalar Etik Kurulu'ndan (07.09.2020 tarih ve 2020-31 sayılı) alınmış, araştırmanın tüm aşamalarında etik kurallara uyulmuştur. Araştırmaya katılanlar araştırmaya gönüllülük esasıyla katılmışlardır. Bu kapsamda öğrencilere araştırmanın amacı ve yöntemi tanıtılmış ve sözlü izinleri de alınmıştır.

\section{Bulgular}

Çalışmanın bu bölümünde, araştırmadan elde edilen nicel bulgular tablolaştırılarak sunulmuş ve bulgulara ilişkin yorumlara yer verilmiştir.

\section{Öğretmen Adaylarının Bilişsel Esneklik Düzeylerine Yönelik Bulgular}

Öğretmen adaylarının bilişsel esneklik düzeyleri tablolaştırılarak aşağıda sunulmuştur.

Tablo 2

Katılımcıların Bilişsel Esneklik Düzeyleri

\begin{tabular}{|c|c|c|c|c|c|c|c|c|}
\hline Boyut & & $\begin{array}{l}\text { ok } \\
\text { şük }\end{array}$ & Düşük & Orta & Yüksek & $\begin{array}{c}\text { Çok } \\
\text { Yüksek }\end{array}$ & $\mathrm{x}$ & ss \\
\hline \multirow[t]{2}{*}{ Alternatif } & $f$ & 1 & 3 & 10 & 189 & 57 & \multirow{2}{*}{4.14} & \multirow{2}{*}{.50} \\
\hline & $\%$ & 0.4 & 1.2 & 3.8 & 72.7 & 21.9 & & \\
\hline \multirow[t]{2}{*}{ Kontrol } & $\mathrm{f}$ & 2 & 23 & 105 & 112 & 18 & \multirow{2}{*}{3.46} & \multirow{2}{*}{.69} \\
\hline & $\%$ & .8 & 8.8 & 40.4 & 43.1 & 6.9 & & \\
\hline \multirow{2}{*}{$\begin{array}{l}\text { Bilişsel Esneklik } \\
\text { Toplam }\end{array}$} & $\mathrm{f}$ & 0.0 & 5 & 28 & 205 & 22 & \multirow{2}{*}{3.90} & \multirow{2}{*}{.48} \\
\hline & $\%$ & 0.0 & 1.9 & 10.8 & 78.8 & 8.5 & & \\
\hline
\end{tabular}

Tablo 2.'de görüldüğü üzere, öğretmen adaylarının bilişsel esneklik düzeyleri düşük ve çok yüksek skalasında dağılım göstermektedir. Katılımcıların bilişsel esneklik düzeyleri hem alt boyutlar altında hem de toplam ölçek puanı olarak incelenmektedir.

"Alternatif" alt boyutu incelendiğinde, katılımcıların ortalama puanlarının ( $\mathrm{x}=4.1$ ) yüksek düzeyde olduğu anlaşılmaktadır. Katılımcıların \%3.8'i (10 katılımcı) orta, \%72.7'si (189 katılımcı) yüksek, \%21.9'u (57 katılımc1) çok yüksek düzeyde yer almaktadır. Yalnızca \%1.2 oranında (3 katılımc1) düşük düzeyde ve $\% 0.4$ oranında (1 katılımc1) çok düşük düzeyde yer almaktadır ve bu bulgu, katılımcıların, zor durumlara alternatif çözümler bulunabileceği ya da yaşam durumları ve insan davranışlarına yönelik olarak alternatif açıklamalar ortaya koyabilme açısından istenilen düzeyde olmadıklarını ortaya koymaktadır. Bu bulgular ışığında, öğretmen adaylarının genel olarak "alternatif" alt boyutu açısından yüksek düzeyde oldukları söylenebilir.

"Kontrol" alt boyutuna bakıldığında, katılımcıların ortalama puanlarının $(x=3.46)$ orta düzeyde olduğu görülmektedir. Katılımcıların \%40.4'ü (105 katılımc1) orta, \%43.1'i (112 katılımc1) yüksek, \%6.9'u (18 katılımcı) çok yüksek düzeyde yer almaktadır. Katılımcıların \%8.8'i (23 katılımcı) düşük, \%0.8'i (2 katılımcı) çok düşük düzeyde yer almaktadır. Bu bulguya göre, düşük ve çok düşük puanlara sahip katılımcıların zor durumların kontrolü açısından zorluklar yaşadıkları ve istenilen düzeyde olmadıkları söylenebilir. 
Toplam bilişsel esneklik düzeylerine bakıldığında, öğretmen adaylarının \%1.9'u (5 kişi) düşük, \% 10.8'i (28 kişi) orta, \%78,8'i (205 kişi) yüksek, \%8,5'i (22 kişi) ise çok yüksek düzeyde oldukları anlaşılmıştır. Öğretmen adaylarının bilişsel esneklik ortalama puanlarının $(x=3,9)$ yüksek düzeyde olduğu söylenebilir.

\section{Öğretmen Adaylarının Kültürel Zekâ Düzeylerine Yönelik Bulgular}

Tablo 3

Öğretmen adaylarının kültürel zekâ düzeyleri tablolaştırılarak aşağıda sunulmuştur.

Katılımcıların Kültürel Zekâ Düzeyleri

\begin{tabular}{|c|c|c|c|c|c|c|c|c|}
\hline Boyut & & $\begin{array}{l}\mathrm{k} \\
\text { şük }\end{array}$ & Düşük & Orta & Yüksek & $\begin{array}{l}\text { Çok } \\
\text { Yüksek }\end{array}$ & $\mathrm{x}$ & SS \\
\hline \multirow[t]{2}{*}{ Üstbiliş } & $\mathrm{f}$ & 0,0 & 4 & 20 & 165 & 71 & \multirow{2}{*}{4,03} & \multirow{2}{*}{,60 } \\
\hline & $\%$ & 0,0 & 1,5 & 7,7 & 63,5 & 27,3 & & \\
\hline \multirow[t]{2}{*}{ Biliş } & $\mathrm{f}$ & 1 & 21 & 142 & 90 & 6 & \multirow{2}{*}{3,20} & \multirow{2}{*}{,60 } \\
\hline & $\%$ & ,4 & 8,1 & 54,6 & 34,6 & 2,3 & & \\
\hline \multirow[t]{2}{*}{ Motivasyon } & $\mathrm{f}$ & 0,0 & 4 & 68 & 128 & 60 & \multirow{2}{*}{3,90} & \multirow{2}{*}{,68 } \\
\hline & $\%$ & 0,0 & 1,5 & 26,2 & 49,2 & 23,1 & & \\
\hline \multirow[t]{2}{*}{ Davranış } & $\mathrm{f}$ & 1 & 8 & 87 & 143 & 21 & \multirow{2}{*}{3,66} & \multirow{2}{*}{, 59} \\
\hline & $\%$ & ,4 & 3,1 & 33,5 & 55,0 & 8,1 & & \\
\hline \multirow{2}{*}{$\begin{array}{l}\text { Kültürel Zekâ } \\
\text { Toplam }\end{array}$} & $\mathrm{f}$ & ,0 & 2 & 91 & 162 & 5 & \multirow{2}{*}{3,66} & \multirow{2}{*}{,45 } \\
\hline & $\%$ & 0,0 & ,8 & 35,0 & 62,3 & 1,9 & & \\
\hline
\end{tabular}

Tablo 3.’te görüldüğü üzere, öğretmen adaylarının kültürel zekâ düzeyleri düşük ve çok yüksek skalasında dağılım göstermektedir. Katılımcıların kültürel zekâ düzeyleri hem alt boyutlar altında hem de toplam ölçek puanı olarak incelenmektedir.

Üstbiliş alt boyutu incelendiğinde, katılımcıların ortalama puanlarının $(\mathrm{x}=4.0)$ yüksek düzeyde olduğu anlaşılmaktadır. Katılımcıların \%7.7'si (20 katılımc1) orta, \%63.5'i (165 katılımc1) yüksek, \%27.3'ü (71 katılımcı) çok yüksek düzeyde yer almaktadır. Yalnızca \%1.5 oranında (4 katılımcı) düşük düzeyde yer almaktadır ve bu katılımcıların, sahip oldukları kültürel bilgiler üzerinde kontrol sahibi olup olmamayı ve sahip oldukları kültürel bilgileri anlamada kullandıkları zihinsel süreçleri yansıtan üst biliş boyutunda istenilen düzeyde olmadıkları söylenebilir. Ulaşılan bulgulara göre, öğretmen adaylarının genel olarak üst biliş boyutuna ait puanlarının yüksek olduğu sonucuna ulaşılmaktadır.

Biliş alt boyutu incelendiğinde, katılımcıların ortalama puanlarının $(x=3.2)$ orta düzeyde olduğu anlaşılmaktadır. Katılımcıların \%54.6'sı (142 katılımc1) orta, \%34.6's1 (90 katılımc1) yüksek, \%2.3’ü (6 katılımcı) çok yüksek düzeyde yer almaktadır. Ayrıca, \%8.1 oranında katılımcı (21 kişi) düşük düzeyde, 0.4 oranında katılımcı da (1 kişi) çok düşük düzeyde yer almaktadır ve bu katılımcıların, farklı kültürler hakkında sahip oldukları bilgileri yansıtan biliş boyutunda istenilen düzeyde olmadıkları söylenebilir. Ulaşılan bulgulara göre, öğretmen adaylarının genel olarak biliş boyutuna ait puanlarının orta düzeyde olduğu sonucuna ulaşılmaktadır.

Motivasyon alt boyutu incelendiğinde, katılımcıların ortalama puanlarının ( $\mathrm{x}=3.9)$ yüksek düzeyde olduğu anlaşılmaktadır. Katılımcıların \%26.2'si (69 katılımc1) orta, \%55'i (143 katılımc1) yüksek, \%23.1'i (60 katılımcı) çok yüksek düzeyde yer almaktadır. Ayrıca, \%1.5 oranında katılımcı (4 kişi) düşük düzeyde yer almaktadır ve bu katılımcıların, farklı kültürlerden insanlarla etkileşime girme konusundaki ilgi ve bu konudaki öz yeterlik inancını yansıtan motivasyon boyutunda istenilen düzeyde olmadıkları söylenebilir. Ulaşılan bulgulara göre, öğretmen adaylarının genel olarak motivasyon boyutuna ait puanlarının yüksek düzeyde olduğu sonucuna ulaşılmaktadır.

Davranış alt boyutu incelendiğinde, katılımcıların ortalama puanlarının ( $\mathrm{x}=3.7)$ yüksek düzeyde olduğu anlaşılmaktadır. Katılımcıların \%33.5'i (87 katılımc1) orta, \%49.2'si (128 katılımc1) yüksek, \%8.1'i (21 katılımcı) çok yüksek düzeyde yer almaktadır. Ayrıca, \%3.1 oranında katılımcı (8 kişi) düşük düzeyde, \%0.4 oranında katılımcı (1 kişi) çok düşük düzeyde yer almaktadır ve bu 
katılımcıların, farklı kültürel geçmişe sahip insanlarla karşılaştığında uygun sözel ya da sözel olmayan davranışları sergileyebilme yeteneğini yansıtan davranış boyutunda istenilen düzeyde olmadıkları söylenebilir. Ulaşılan bulgulara göre, öğretmen adaylarının genel olarak davranış boyutuna ait puanlarının yüksek düzeyde olduğu sonucuna ulaşılmaktadır.

Kültürel Zekâ Ölçeği, toplam puanlar üzerinden ele alındığında, katılımcıların ortalama puanlarının ( $\mathrm{x}=3.7)$ yüksek düzeyde olduğu görülmektedir. Katılımcıların \% 35.0'i (91 katılımc1) orta, \%62.3'ü (162 katılımc1) yüksek, \%1.9'u (5 katılımc1) çok yüksek düzeyde yer almaktadır. Bu bulguya dayanarak, öğretmen adaylarının kültürel zekâ düzeylerinin yüksek düzeyde olduğu söylenebilir.

\section{Öğretmen Adaylarının Bilişsel Esneklik Düzeyleri ile Kültürel Zekâ Düzeyleri Arasındaki İlişkiye Dönük Bulgular}

Bu alt başlıkta öğretmen adaylarının kültürel zekâ düzeyleri önce Üst biliş, Biliş, Motivasyon ve Davranış alt boyutlarında tek tek; daha sonra ise toplam puan şeklinde ele alınarak bilişsel esneklik düzeyleri ile arasında bir ilişkinin olup olmadığı sunulmuştur. Yordama analizi her bir inceleme için 2 model altında ele alınmıştır.

Tablo 4

Kültürel Zekâ Düzeyinin Bilişsel Esneklik Düzeyini Yordamasına İlişkin Analiz Sonuçları

\begin{tabular}{|c|c|c|c|c|c|c|c|c|c|}
\hline & $\begin{array}{l}\text { Yordayıcı } \\
\text { Değişken }\end{array}$ & B & $\begin{array}{c}\text { Standart } \\
\text { HataB }\end{array}$ & $\beta$ & $\mathrm{t}$ & $\mathrm{P}^{*}$ & $\begin{array}{l}\text { İkili } \\
\mathrm{r}\end{array}$ & $\begin{array}{c}\text { Kismi } \\
\text { R }\end{array}$ & \\
\hline \multirow[t]{5}{*}{ Model 1} & Sabit & 2,020 & ,218 & & 9,277 & ,000 & & & \multirow{5}{*}{$\begin{array}{l}\text { Çoklu } R \\
=, 53 \\
R^{2}=, 28 \\
\text { Ayarlanmış } \\
R^{2}=, 27 \\
F=24,398 \\
p<0.05\end{array}$} \\
\hline & Üstbiliş &, 257 &, 050 &, 319 & 5,136 &, $000^{*}$ & ,306 &, 274 & \\
\hline & Biliş &,- 025 &, 048 &,- 032 &,- 525 &, 600 &,- 033 &,- 028 & \\
\hline & Motivasyon & ,209 & ,046 & ,295 & 4,549 &, $000 *$ & ,274 & ,242 & \\
\hline & Davranış & ,030 & ,048 & ,037 & ,622 &, 534 & ,039 & ,033 & \\
\hline \multirow[t]{2}{*}{ Model 2} & Sabit & 2,106 & ,219 & & 9,608 & ,000 & & & \multirow{2}{*}{$\begin{array}{l}\text { Çoklu } R= \\
.46 \\
R^{2}=.21 \\
\text { Ayarlanmış } \\
R^{2}=.21 \\
F=68,006 \\
p<0.05\end{array}$} \\
\hline & $\begin{array}{l}\text { Kültürel } \\
\text { Zekâ }\end{array}$ & ,491 & ,059 & ,457 & 8,247 &, $000 *$ & ,457 & ,457 & \\
\hline
\end{tabular}

Analize tabi tutulan ilk model, öğretmen adaylarının bilişsel esneklik düzeylerini yordamada anlamlıdır [R2=.28, Ayarlanmış $\mathrm{R} 2=.27, \mathrm{~F}=24.398, \mathrm{p}<.05]$. Öğretmen adaylarının üst biliş puanları, bilişsel esneklik puanlarını anlamlı olarak yordamaktadır $(\beta=.319, \mathrm{p}<.05)$. Biliş puanları, bilişsel esneklik puanlarını anlamlı olarak yordamamaktadır $(\beta=-.032, \mathrm{p}>.05)$. Motivasyon puanları, bilişsel esneklik puanlarını anlamlı olarak yordamaktadır $(\beta=, 295 \mathrm{p}<.05)$. Davranış puanları, bilişsel esneklik puanlarını anlamlı olarak yordamamaktadır $(\beta=, 037 \mathrm{p}>.05)$. Bu sonuçlara göre, öğretmen adaylarının üst biliş ve motivasyon puanları bilişsel esneklik düzeyini olumlu yönde etkilerken, biliş ve davranış puanları etkilememektedir. Regresyon modeli denklemi aşağıdaki gibidir:

$$
\text { Bilişsel Esneklik }=2.020+(.257 * \text { Üstbiliş })+(.209 * \text { Motivasyon })
$$

Analize dahil edilen ikinci model, öğretmen adaylarının bilişsel esneklik düzeylerini yordamada anlamlıdır [ $\mathrm{R} 2=.21$, Ayarlanmış $\mathrm{R} 2=.21, \mathrm{~F}=68.006, \mathrm{p}<.05]$. Öğretmen adaylarının kültürel zekâ toplam puanları, bilişsel esneklik puanlarını anlamlı olarak yordamaktadır $(\beta=.457, \mathrm{p}<.05) . \mathrm{Bu}$ sonuca göre, öğretmen adaylarının kültürel zekâ toplam puanları, bilişsel esneklik düzeyini olumlu yönde etkilemektedir. Regresyon modeli denklemi aşağıdaki gibidir:

Bilişsel Esneklik $=2.106+(.491 *$ Kültürel Zekâ $)$ 


\section{Sonuç, Tartışma ve Öneriler}

Araştırmanın ilk bulgusuna göre, öğretmen adaylarının bilişsel düzeylerinin yüksek olduğu görülmektedir. Araştırmanın bu bulgusu, Temel Eğitim Bölümü'nde öğrenim görmekte olan öğretmen adaylarıyla çalışan Esen Aygün (2018), öğretmenler ve Eğitim Fakültelerinin 4. sınıflarında öğrenim görmekte olan öğretmen adaylarıyla çalışan Çuhadaroğlu (2013) ve üstün zekâlılar öğretmenliği adaylarıyla çalışan Camcı Erdoğan'ın (2018) bulgularıyla uyuşmaktadır. Bununla birlikte alt boyutlar açısından ele alındığında, alternatif alt boyutuna ait puanların kontrol boyutuna ait puanlardan daha yüksek olduğu anlaşılmıştır. Araştırmanın bu bulgusu, üstün zekâlılar öğretmen adaylarının alternatifler alt boyutu puanlarını ve kontrol alt boyutu puanlarını yüksek düzeyde bulan Camcı Erdoğan'ın (2018) bulgularıyla uyuşmamaktadır. Olaylar karşısında alternatiflerin farkında olan bireyler, farkında olmayanlara göre bilişsel yönden daha esnektirler ve bu bireyler başka insanların duygularının da farkındadırlar. Bilişsel esneklik düzeyinin yükselmesiyle olumlu yaşantıların daha fazla yaşanacağına ve bunun sonucunda bireyin yaşam doyumunun yüksek olacağına inanılmaktadır (Aydınay-Satan, 2014).

Bununla birlikte, zor durumlar karşısında kontrollü olmak ve bu durumlar üzerinde hakimiyetini korumak, yani "kontrol" boyutu açısından öğretmen adaylarının istenilen düzeyde olmadıkları anlaşılmaktadır. Eğitim-öğretim sürecinin verimliliği açısından öğretmen adaylarının bilişsel esneklik düzeylerinin yüksek olması önemlidir çünkü ilerideki meslek hayatlarında öğrencilerin bilişsel esneklik kazanmalarında etkili bir aktör haline dönüşeceklerdir. Bu kapsamda, öğretmen adaylarının hizmet öncesi eğitimleri boyunca bilişsel esneklik düzeylerini yükseltmek için, literatürde bilişsel esneklikle ilgili olduğu düşünülen eleştirel düşünme, problem çözme vb. becerileri kazandırmaya dönük ders içerikleri ve etkinliklere yer verilmeli; eğitim fakültelerinde görev yapan akademisyenlerin bilişsel esneklik düzeyleri farklı araştırmalarla ortaya konulmalı ve politika yapıcılar tarafından bu bulgulara dayalı olarak üretilen sorun çözücü bakış açıları hizmet öncesi öğretmen eğitiminde kendine yer bulmalıdır.

Araştırmada ulaşılan ikinci bulgu, öğretmen adaylarının kültürel zekâ düzeylerinin yüksek olmasıdır. Araştırmanın bu bulgusu, 241 Türkçe öğretmeni adayıyla çalışıp, kültürel zekâya ait puan ortalamalarını ortanın üstü olarak bulan İnan'ın (2017) bulgularıyla örtüşmektedir. Bununla birlikte, alt boyutlar açısından değerlendirildiğinde, biliş ve davranış puanlarının, üst biliş ve motivasyon puanlarının gerisinde olduğu görülmektedir. Araştırmanın bu bulgusu, çalışmasında biliş boyutunu en düşük ortalamaya sahip olarak ortaya çıkaran Koçak ve Özdemir'in (2016) bulgusuyla uyuşmaktadır. Koçak ve Özdemir'in (2016) çalışmasında, öğretmen adayları kültürel zekâya ait boyutların üçünde (üst biliş, motivasyon ve davranış) oldukça yüksek, tek bir boyutta (biliş) ise orta düzeyde bir ortalamaya sahiptir. İlhan ve Çetin'in (2014b) çalışmasında da boyutlara ait ortalamaların büyükten küçüğe doğru üst biliş, motivasyon, davranış ve biliş şeklinde sıralandığı ortaya çıkmıştır.

Kültürel zekânın biliş boyutu, bireyin günlük deneyimler yardımıyla ya da formal eğitim yoluyla diğer kültürler hakkında edindiği bilgileri içerdiği ve bu bilgiler arasında diğer kültürlerin sosyal yapıları, ekonomik ve yasal sistemleri yer aldığı dikkate alındığında (Yaşar Ekici, 2017), öğretmen adaylarının diğer kültürler hakkında yeterli formal ve informal bilgiye sahip olmadığı söylenebilir. Kültürel zekânın davranış boyutunun, kişinin farklı kültürel geçmişe sahip bireylerle karşılaştı̆̆ında uygun sözel ya da sözel olmayan davranışları sergileyebilmesi anlamına geldiği ve kültürel zekânın davranış boyutu gelişmiş olan bireylerin ses tonu ve konuşma hızı gibi sözel davranışlarıyla jest ve mimik gibi sözel olmayan davranışlarını etkileşimde bulundukları kültürlerin gereklerine göre ayarlayabilme konusunda başarılı oldukları dikkate alındığında (Yaşar Ekici, 2017), öğretmen adaylarının bulundukları çevre nedeniyle farklı kültürel arka plan değişkenlerine sahip bireylerle bir arada bulunmamalarının bu sonucun ortaya çıkmasında etkili olduğu ifade edilebilir. Kültürel zekânın geliştirilebilir bir zekâ türü olduğu düşünüldüğünde, öğretmen adaylarının ülkesinde ve dünyadaki farklı kültürel arka planlardan gelen bireyleri tanımaları, onlarla etkileşimde olmalarının önemi daha da artmaktadır. Aynı zamanda öğretmen adaylarının, gelecekteki meslek hayatlarında farklı etnik ve kültürel kökenlerden öğrencileri olacağı unutulmamalı; bu kapsamda hizmet öncesi öğretmen yetiştirme programlarında çok kültürlülük ve eğitimsel boyutu, "Eğitim Sosyolojisi" dersi 
ötesinde ele alınmalıdır. Nitekim, Cırık (2008), çok kültürlü eğitime yönelik tanımlamalarda ortak kavramların, "insan haklarına saygı duyma, kültürel farklılıkları hoş karşılama, eğitimde firsat eşitliği, kültürel çeşitliliği yansıtıcı eğitim ortamları düzenleme, farklı bakış açılarını ve fikirleri analiz etme" açısından birleştiğini ifade etmektedir. Bununla birlikte, Thomas ve Inkson (2005), kültürel zekânın geliştirilmesinde tecrübeye dayalı ögrenmenin daha etkin bir yöntem olduğunu belirtmiştir.

Araştırmada ulaşılan son bulguya göre, öğretmen adaylarının üst biliş ve motivasyon puanları, bilişsel esneklik düzeylerini olumlu yönde etkilemektedir. Bir başka ifadeyle, diğer kişilerin kültürel tercihleri ile ilgili bilişsel farkındalık gösteren (üst biliş) ve kültürlerarası tecrübeler geçirme ve farklı kültürel ortamlara uyum sağlama noktasındaki iç motivasyonu ve öz yeterliliğe (motivasyon) sahip bireylerin bilişsel esneklik düzeylerinin yüksek olduğu söylenebilir. Ayrıca öğretmen adaylarının kültürel zekâ toplam puanları, bilişsel esneklik puanlarını anlamlı olarak yordamaktadır $(\beta=.457$, $\mathrm{p}<.05)$. Bu sonuca göre, öğretmen adaylarının kültürel zekâ toplam puanları, bilişsel esneklik düzeyini olumlu yönde etkilemektedir. Bir başka ifadeyle, çevrelerinde yaşanan olaylar ve insanlar arasındaki karmaşık ilişkilerini anlama ve algılama açısından zengin insanlar (Yeşil, 2009), diğerlerine göre daha fazla bakış açılarını mekansal veya kişilerarası olarak değiştirmek için kavramsal temsiller arasında geçiş yapma yeteneğine ve olguları farklı bakış açılarından görebilme yeteneğine, yani daha üst düzey bilişsel esnekliğe sahiptirler denebilir.

$\mathrm{Bu}$ çalışmada ele alınan bilişsel esneklik ve kültürel zekâ değişkenlerinin her ikisi de, literatürde s1klıkla anılan (Barak ve Levenberg, 2016; Guzman, Durden, Taylor, Guzman ve Potthoff, 2016; Herrmann, 2015; SHRM Foundation, 2015; Willis, 2016) 21. Yüzy1l becerilerindendir. Dolayısıyla, nitelikli bir eğitim sisteminin Endüstri 4.0 döneminde üretmesi beklenen temel çıktılardandır. Bu kapsamda, özellikle bu öğrencileri yetiştirecek öğretmenlerin hizmet öncesi eğitimlerinde, öğretmen adaylarının bu becerileri edinmesi kaçınılmaz bir gereklilik olarak karşımıza çıkmaktadır. Ders içerikleri, öğretme süreçleri ve yöntemlerinin bu ihtiyaç çerçevesinde yeniden ele alınması gerektiği söylenebilir. Medya sosyolojisinde sıklıkla kullanılan iki terim üzerinden örnek vermek gerekirse, eğer eğitim sistemimizde bu dönüşümler gerçekleştirilmezse Endüstri 4.0 toplumunda dijital yerliler, dijital göçmenlerin sınırlarının hayli ötesine geçecek ve geleceğin öğretmenleri sınıflarında öğrencilerine rol kaptıracaktır demektir. Bunun önüne geçebilmek için ise, hizmet öncesi öğretmen yetiştirme sistemimizin revize edilmesi yaşamsal bir ihtiyaç olarak belirmektedir. Nitekim Yü ksek Öğretim Kurulu'nun 18 Ağustos 2020 tarihinde açıklanan kararında (Anadolu Ajans1, 2020), öğretmenlik programlarının ders, müfredat ve kredilerinin belirlenmesinde Eğitim Fakülteleri'ne yönelik yetki devri bu açıdan olumlu bir adım olarak değerlendirilebilir.

\section{Yazarların Katkı Oranı}

Çalışma tek yazarlı olduğu için yazarın katkı oranı \%100’dür.

\section{Çıkar Çatışması}

Çıkar çatışması teşkil edebilecek bir durum yoktur.

\section{Kaynaklar}

Alexandra, V., Ehrhart, K. H. and Randel, A. E. (2021). Cultural intelligence, perceived iclusion, and cultural diversity in Workgroups. Personality and Individual Differences, 168, 1-6.

Aliaga, M. and Gunderson, B. (2002). Interactive statistics. Thousand Oaks, Sage Publications: UK.

Alon, I. and Higgins, J. H. (2005). Global leadership success through emotional and cultural intelligence. Business Horizons, 48, 501-512. 
Anadolu Ajansı (2020). YÖK Başkanı Saraç: Öğretmenlik programlarının ders, müfredat ve kredilerine yüksekögretim kurumları karar verecek. 18 Ağustos 2020 tarihli haber. 20.08.2020 tarihinde https://www.aa.com.tr/tr/egitim/yok-baskani-sarac-ogretmenlik-programlarinin-dersmufredat-ve-kredilerine-yuksekogretim-kurumlari-karar-verecek/1945375 web adresinden erişilmiştir.

Ang, S., Van Dyne, L., Koh, C., Yee Ng, K., Templer, K. J., Tay, C. and Chandrasekar, N. A. (2007). Cultural intelligence: Its measurement and effects on cultural judgment and decision making, cultural adaptation and task performance. Management and Organization Review, 3 (3), 335371.

Ang, S. and Van Dyne, L. (2015). Handbook of cultural intelligence: Theory, measurement and applications. Routledge: UK.

Aydınay Satan, A. (2014). Dini inanç ve bilişsel esneklik düzeylerinin öznel iyi oluş düzeyine olan etkisi. 21. Yüzyllda Ĕ̈itim ve Toplum Dergisi, 7 (3), 50-74.

Azevedo, A. and Shane, M. J. (2019). A new training program in developing cultural intelligence can also improve innovative work behavior and resilience: A longitudinal pilot study of graduate students and professional employees. The International Journal of Management Education, $17,1-20$.

Barak, M. and Levenberg, A. (2016). Flexible thinking in learning: an individual differences measure for learning in technology-enhanced environments. Computers and Education, 99, 39-52.

Bilgin, M. (2009). Bilişsel esnekliği yordayan bazı değişkenler. Çukurova Üniversitesi Eğitim Fakültesi Dergisi, 3(6), 142-157.

Blair, C. and Peters, R. (2003). Physiological and neurocognitive correlates of adaptive behavior in preschool among children in Head Start. Developmental Neuropsychology, 24, 479-497.

Brancu, L., Munteanu, V. and Golet, I. (2016). Understanding Cultural Intelligence Factors Among Business Students in Romania. Procedia - Social and Behavioral Sciences, 221, 336 - 341.

Büyüköztürk, Ş., Çakmak Kılıç, E., Akgün, Ö. E., Karadeniz, Ş. ve Dermirel, F. (2012). Bilimsel araştırma yöntemleri. Ankara: Pegem Akademi.

Camcı Erdoğan, S. (2018). Üstün zekâlılar öğretmenliği adaylarının bilişsel esneklik düzeylerinin incelenmesi. Manisa Celal Bayar Üniversitesi Sosyal Bilimler Enstitüsü Dergisi, 16 (3),77-96.

Cheng, J. and Koszalka, T. A. (2016). Cognitive flexibility theory and its application to learning resources. Retrieved from http://ridlr.syr.edu/wp-content/uploads/2016/09/CFT_FInal.pdf on August 5, 2019.

Chieu, V. M. (2007). An operational approach for building learning environments supporting cognitive flexibility. Educational Technology \& Society, 10 (3), 32-46.

Cırık, İ. (2008). Çok kültürlü eğitim ve yansımaları. Hacettepe Üniversitesi Eğitim Fakültesi Dergisi, $34,27-40$.

Coulson, R. L., Feltovich, P. J. and Spiro, R. J. (1997). Cognitive flexibility in medicine: An application to the recognition and understanding of hypertension. Advances in Health Sciences Education, 2, 141-161. 
Creswell, J. W. (2011). Educational research: Planning, conducting, and evaluating quantitative and qualitative research (4th Edition). Pearson: UK.

Crowne, K. A. (2008). What leads to cultural intelligence? Business Horizons,391-399.

Çelikkaleli, Ö. (2014a). The validity and reliability of the cognitive flexibility scale. Education and Science, 39 (176), 339-346.

Çelikkaleli, Ö. (2014b). Ergenlerde bilişsel esneklik ile akademik, sosyal ve duygusal yetkinlik inançları arasındaki ilişki. Ĕgitim ve Bilim, 39 (176), 347-354.

Çuhadaroglu, A. (2013).Bilişsel esnekliğin yordayıcıları. Cumhuriyet Uluslararası Eğitim Dergisi, $2(1), 86-101$.

Dajani, D. R. and Uddin, L. Q. (2015). Demystifying cognitive flexibility: Implications for clinical and developmental neuroscience. Trends in Neurosciences, 38 (9),571-578.

Dangmei, J. (2016). Cultural intelligence: bridging the cultural differences in the emerging markets. Paripex Indian Journal of Research, 5(9), 284-287.

Darabi, A., Hemphill, J., Nelson, D. W., Boulware, W. and Liang, X. (2010). Mental model progression in learning the electron transport chain: Effects of instructional strategies and cognitive flexibility. Advances in Health Sciences Education, 15,479-489.

Davidson, M. C., Amso, D., Anderson, L. C. and Diamond, A. (2006). Development of cognitive control and executive functions from 4 to 13 years: Evidence from manipulations of memory, inhibition, and task switching. Neuropsychologia, 44, 2037-2078.

De Mooij, M. (2011). Consumer behavior and culture: Consequences for global marketing and advertising. Sage Publications, Inc: UK.

Deng, L and Gibson, P. (2008), A Qualitative Evaluation On The Role of Cultural Intelligence In Cross - Cultural Leadership Effectiveness, International Journal of Leadership Studies, 3 (2), 181-197.

Dennis, J. P. and Vander Wal, J. S. (2010). The cognitive flexibility inventory: Instrument development and estimates of re-liability and validity. Cognitive Therapy and Research, $34,241-253$.

Diamond, A. (2013). Executive functions. Annual Review of Psychology, 64, 135-168.

Earley, P. C. and Mosakowski, E. (2004). Cultural intelligence. Harvard Business Review, 82 (10), 139-146.

Esen Aygün, H. (2018). Öğretmen adaylarının bilişsel esneklik düzeyleri ile kişilerarası problem çözme becerileri arasındaki ilişkinin incelenmesi. Eurasian Journal of Educational Research, $77,105-128$.

Feltovich, P.J., Spiro, R.J., Coulson, R.L. and Feltovich, J. (1996). "Collaboration within and among minds: Mastering complexity, individually, and in groups", in Koschmann, T.:CSCL: Theory and practice of emerging paradigm, Mahweh, NJ: Erlbaum.

Göl, İ. and Erkin, Ö. (2019). Association between cultural intelligence and cultural sensitivity in nursing students: A cross-sectional descriptive study. Collegian, 26, 486-491. 
Guzman, M.R.T., Durden, T.R., Taylor, S.A., Guzman, J.M. and Potthoff, K.L. (2016). Cultural competence: an important skill set for the 21st century. Retrieved from https://extensionpublications.unl.edu/assets/html/g1375/build/g1375 in August 2, 2020.

Gündüz, B. (2013). The contributions of attachment styles, irrational beliefs and psychological symptoms to the prediction of cognitive flexibility. Educational Sciences: Theory and Practice, 13 (4), 2079-2085.

Harrison, J. K., and Brower, H. H. (2011). The Impact of Cultural Intelligence and Psychological Hardiness on Homesickness among Study Abroad Students. Frontiers: The Interdisciplinary Journal of Study Abroad, Vol: 21 pp. 41-62.

Henderson, L.S., Stackman, R. W. and Lindekilde, R. (2018). Why cultural intelligence matters on global project teams? International Journal of Project Management, 36, 954-967.

Herrmann, E. (2015). Cultural competence in the classroom: a key 21st- century skill. Retrieved from http://exclusive.multibriefs.com/content/cultural-competence-in-the-classroom-a-key-21stcentury-skill/education in December 2, 2019.

Ionescu, T. (2012). Exploring the nature of cognitive flexibility. New Ideas in Psychology, 30, pp. 190 -200 .

İlhan, M. ve Çetin, B. (2014a). Kültürel zekâ ölçeği'nin Türkçe formunun geçerlik ve güvenirlik çalışması. Hacettepe Üniversitesi Eğitim Fakültesi Dergisi, 29 (2),94-114.

İlhan, M. ve Çetin, B. (2014b). Sosyal ve kültürel zekâ arasındaki ilişkinin yapısal eşitlik modeli ile incelenmesi. Turkish Journal of Education, 3 (2), 4-15.

İnan, K. (2017). Türkçe öğretmeni adaylarında kültürel zekânın çeşitli değişkenlere göre incelenmesi. Hacettepe Üniversitesi Yabancı Dil Olarak Türkçe Araştırmaları Dergisi, Sayı: 3, s. 21-33.

Johnco, C., Wuthrich, V. M. and Rapee, R. M. (2014). The influence of cognitive flexibility on treatment outcome and cognitive restructuring skill acquisition during cognitive behavioural treatment for anxiety and depression in older adults: Results of a pilot study. Behaviour Research and Therapy, 57, 55-64.

Kaptanbaş Gürbüz, E., ve Sezgin Nartgün, Ş. (2018). Pedagojik formasyon programı öğrencilerinin bilişsel esneklik ve öz yeterlik düzeyleri. Uluslararası Sosyal Araştırmalar Dergisi, 11 (55), 628-640.

Kercood, S., Lineweaver, T. T., Frank, C.C. and Fromm, E. D. (2017). Cognitive flexibility and its relationship to academic achievement and career choice of college students with and without attention deficit hyperactivity disorder. Journal of Postsecondary Education and Disability, 30 (4), 329-344.

K1lıç, F. ve Demir, Ö. (2012). Sınıf öğretmenliği öğrencilerinin bilişsel koçluk ve bilişsel esnekliğe dayalı ögretim ortamlarının oluşturulmasına ilişkin görüşleri. İlköğretim Online, 11(3), 578595.

Knudsen, H. B. S., Lopez, K. J. and Archibald, L. M. D. (2018). The contribution of cognitive flexibility to childrens' reading comprehension - the case for Danish. Journal of Research in Reading, 41 (1), 130-148.

Koçak, S., ve Özdemir, M. (2015). Öğretmen adaylarının çok kültürlü eğitime yönelik tutumlarında kültürel zekânın rolü. İlkögretim Online, 14 (4), 1352-1369. 
Kolburan, Ş. G., Eken, E. ve Akdeniz, B. (2019). Bilişsel esneklik ve mizah stilleri arasındaki ilişkinin değerlendirilmesi. Türkiye Klinikleri Journal of Forensic Medicine and Forensic Sciences, 16 (1), 1-13

Koşar, M. B. (2019). Üstün ve normal zekâ düzeyindeki ergenlerde bilişsel esneklik ve özdüzenleyici ögrenme becerileri arasındaki ilişkinin incelenmesi. Yüksek Lisans Tezi, Yakın Doğu Üniversitesi, Lefkoşa, KKTC.

Li, M. (2020). An examination of two majör constructs of cross-cultural competence: cultural intelligence and intercultural competence. Personality and Individual Differences, 164, 1-6.

Liamputtong, P. (2016). Research methods in health: foundations for evidance-based practice (Third Edition). Oxford University Press: UK.

Lorenz, M. P., Ramsey, J. R, and Richey, R. G. J. (2018). Expatriates' international oppurtunity recognition and innovativeness: The role of metacognitive and cognitive cultural intelligence. Journal of World Business, 53, 222-236.

Malek, M. A. and Budhwar, P. (2013). Cultural intelligence as a predictor of expatriate adjustment and performance in Malaysia. Journal of World Business, 48, 222-231.

Martin, M. M. and Anderson, C. M. (1998). The cognitive flexibility scale: Three validity studies. Communication Reports, 11, 1-9.

Memari, A. M., Ziaee, V., Shayestehfar, M., Ghanouni, P., Mansournia, M. A. and Moshayedi, P. (2013). Cognitive flexibility impairments in children with autism spectrum disorders: Links to age, gender and child outcomes. Research in Developmental Disabilities, 34, 3218-3225.

Nilsson, S. and Truong, X.D. (2012). The recurring understanding of cultural intelligence: $a$ qualitative study of companies in the forestry based industry in Sweden. Master Thesis, Umea School of Business and Economics, Sweden.

Peker, A. ve Çukadar, F. (2016). Bilişsel esneklik ile sosyal medyayı kullanmaya yönelik tutum arasındaki ilişkinin incelenmesi. Sakarya University Journal of Education, 6(2),66-79.

Pena-Acuna, B. and Pisonero, C. G. (2017). Ethnography and emotions: cultural intelligence applied to motherhood migration process. Procedia - Social and Behavioral Sciences, 237, 446 - 451.

Petrovic, D. S. (2011). Teachers for the Knowledge Society: How do teachers perceive their cultural intelligence? Procedia Social and Behavioral Sciences, 11, 276-280.

Powell, E. M. and Ragozzino, M. E. (2017). Cognitive flexibility: Development, disease and treatment. Neuroscience, 345, 1-2.

Presbitero, A. (2016). Culture shock and reverse culture shock: The moderating role of cultural intelligence in international students' adaptation. International Journal of Intercultural Relations, 53, 28-38.

Presbitero, A. and Quita, C. (2017). Expatriate career intentions: Links to career adaptability and cultural intelligence. Journal of Vocational Behaviour, 98, 118-126.

Rathgeb-Schnierer, E. and Green, M. (2017). Profiles of cognitive flexibility in arithmetic reasoning: A cross-country comparison of German and American elementary students. Journal of Mathematics Education, 10 (1), 1-16. 
Sapmaz, F., ve Doğan, T. (2013). Bilişsel esnekliğin değerlendirilmesi: Bilişsel esneklik envanteri Türkçe versiyonunun geçerlik ve güvenirlik çalışmaları. Ankara Üniversitesi Ĕ̈itim Bilimleri Fakültesi Dergisi, 46 (1), 143-161.

SHMR Foundation. (2015). Cultural intelligence: the essential intelligence fort he 21st century. Retrieved from https://www.shrm.org/hr-today/trends-and-forecasting/special-reports-andexpert-views/Documents/Cultural-Intelligence.pdf in October 2, 2019.

Spiro, R. J., Coulson, R. L., Feltovich, P. J. and Anderson, D. (1988). Cognitive flexibility theory: Advanced knowledge acquisition in ill-structured domains. Tenth Annual Conference of the Cognitive Science Society (pp. 375-383). Hillsdale, NJ: Lawrence Erlbaum. [Reprinted in R. B. Ruddell and M. R. Ruddell (Eds.), Theoretical models and processes of reading (5th ed.). Newark, DE: International Reading Association, pp. 640-654.]

Spiro, R. J., Feltovich, P. J., Jacobson, M. J. and Coulson, R. L. (1992). Cognitive flexibility, constructivism and hypertext: Random access instruction for advanced knowledge acquisition in ill-structured domains. In T. M. Duffy and D. H. Jonassen (Eds.), Constructivism and the technology of instruction (pp. 57-75). Hillsdale, NJ: Lawrence Erlbaum Associates.

Spiro, R.J., Vispoel, W., Schmitz, J., Samarapungavan, A. and Boerger, A. (1987). Knowledge acquisition for application: Cognitive flexibility and transfer in complex content domains. In B.C. Britton (Ed.), Executive control processes (177-200). Hillsdale, NJ: Lawrence Erlbaum.

Stevens, A. D. (2009). Social problem-solving and cognitive flexibility: Relations to social skills and problem behavior of at-risk young children. Unpublished Doctorate Thesis. Seattle Pacific University, School of Psychology, Family, \& Community, U.S.

Thomas, D. C., and Inkson, K. (2005). Cultural Intelligence: people skills for a global workplace. Consulting to Management, 16 (1), 5-9.

Thomas, D.C., Liao, Y., Aycan, Z., Cerdin, J.-L., Pekerti, A.A., Ravlin, E.C., Stahl, G.K., Lazarova, M.B., Fock, H., Arli, D., Moeller, M., Okimoto, T.G. and van de Vijver, F. (2015). Cultural intelligence: a theory-based, short form measure. Journal of International Business Studies, 46 (9),1099-1118.

Triandis, H.C. (2006). Cultural intelligence in organizations. Group \& Organizational Management, 31,20-26.

Van Dyne, L., Ang, S. and Livermore, D. (2010). Cultural intelligence: a pathway for leading in a rapidly globalizing World. In K. M. Hannum. B. McFeeters, and L. Booysen (Eds.), Leading across differences: Cases and perspectives, pp. 131-139. San Francisco, CA: US.

Willis, J. (2016). Building students' cognitive flexibility. Retrieved from https://www.edutopia.org/blog/building-students-cognitive-flexibility-judy-willis in June 2, 2019.

Yaşar Ekici, F. (2017). Okul öncesi öğretmen adaylarının kültürel zekâ düzeyleri ve çok kültürlü eğitime yönelik tutumları. Kastamonu Ĕ̈itim Dergisi, 25 (5),1941-1956.

Yaşar Ekici, F. ve Balcı S. (2019). Okul öncesi öğretmen adaylarının bilişsel esneklik düzeyleri ve duygusal tepkisellik düzeylerinin incelenmesi. Yüksekögretim ve Bilim Dergisi/Journal of Higher Education and Science, 9 (1), 65-77. https://doi.org/10.5961/jhes.2019.310 
Yeşil, S. (2009). Kültürel farklılıkların yönetimi ve alternatif bir strateji: kültürel zekâ. $K M U$ İIBF Dergisi, 11 (16), 100-131.

Ziyatdinova, E. (2017). The role of cultural intelligence from the perspective of leader. Retrieved from https://www.theseus.fi/bitstream/handle/10024/130322/Elvira\%20Ziyatdinova\%20thesis\%20 MAY2017\%20Arcada.pdf?sequence=1 in June 3, 2020. 


\section{Extended Abstract}

\section{Introduction}

Cognitive flexibility is one of the qualifications that teachers should have and should gain the students they will train (Kılıç and Demir, 2012). It is observed that, individuals who have cognitive flexibility; with characteristics such as displaying harmonious and positive attitudes, being careful, analytical and open to changes, undertaking multiple tasks simultaneously, and having the ability to benefit from clues in case of sudden situations and the characteristics of teachers, such as having a confident attitude, behaving friendly, seeing students as individuals, acting politely and respectfully, and ensuring their active participation in activities overlap with each other (Kaptanbaş Gürbüz ve Sezgin Nartgün, 2018). In the words of Yaşar Ekici and Balc1 (2019), the teaching profession is one of the professions with the highest probability of encountering different people, temperaments and behaviors, as it is a profession that includes direct interaction with people. For this reason, it is important for the practitioners of the teaching profession to have a high level of cognitive flexibility in order to adapt to such different situations and produce alternatives.

The other dimension of the study is cultural intelligence. Today, it is universally accepted that intelligence is not only in the classroom, it is part of a larger picture and belongs to a real world created by the social aspect (social intelligence), emotional aspect (emotional intelligence) and practical intelligence (Ziyatdinova, 2017). A person with high emotional intelligence grasps what makes us human and also what makes each of us different from each other. A person with high cultural intelligence can somehow understand from the behavior of a person or group the characteristics that apply to all people and all groups, those specific to this person or group, and those that are neither universal nor unique. The vast area that lies between these two poles is culture (Earley and Mosakowski, 2004). Whether the preservice teachers' cultural intelligence levels predicted their cognitive flexibility constitutes the main problem of the study. It can be said that the findings of the research will be beneficial for decision makers who shape educational policies, academicians who try to look at the subject from different angles and scientific disciplines, and teachers who try to perfect their teaching processes.

In this context, the main problem of the study is whether the cultural intelligence levels of the teacher candidates predict their cognitive flexibility levels. It can be said that the findings of the research will be beneficial for decision makers who shape educational policies, academicians who try to look at the subject from different angles and scientific disciplines, and teachers who try to perfect their teaching processes.

\section{Method}

The study is a quantitative research and is designed as a relational research. Quantitative research is based on the analysis of data collected using statistical mathematical methods to explain facts (Aliaga and Anderson, 2002). The research universe consists of teacher candidates studying at the COMU Faculty of Education. Convenience sampling method was preferred in sample selection. Sample size consists of 260 participants. The sample consists of individuals studying in the departments of English Language Teaching, Science Teaching, Social Studies Teaching, Japanese Teaching, and Turkish Language Teaching. In the data collection process of the study, the Cognitive Flexibility Inventory developed by Sapmaz and Doğan (2013) and the Cultural Intelligence Scale adapted into Turkish by İlhan and Çetin (2014) were used. In the interpretation of quantitative data, $p$ $=0.5$ level was sought for the significance of the difference. Descriptive statistical techniques were used for the first and second research questions; In this context, frequency, percentage, arithmetic mean and standard deviation values were calculated. Multiple regression analysis was performed for the third research question. SPSS 23.0 package program was used to analyze the quantitative data. 


\section{Result, Discussion and Conlusion}

According to the first finding of the study, it is seen that the cognitive levels of the teacher candidates are high. However, it is understood that pre-service teachers are not at the desired level in terms of being in control of difficult situations and maintaining their dominance over these situations, that is, in terms of "control" dimension. High levels of pre-service teachers' cognitive flexibility is important in terms of the efficiency of the educational process because they will become an effective actor in gaining cognitive flexibility for students in their future professional lives. In this context, in order to increase the cognitive flexibility levels of pre-service teachers during their pre-service training, course contents and activities aimed at gaining skills in critical thinking, problem solving, etc. which are thought to be related to cognitive flexibility in the literature should be included.

The second finding reached in the study is that the teacher candidates have high levels of cultural intelligence. However, when evaluated in terms of sub-dimensions, it is seen that the cognition and behavior scores are behind the metacognition and motivation scores. Considering that the cognition dimension of cultural intelligence includes the information that the individual acquires about other cultures with the help of daily experiences or through formal education and this information includes the social structures, economic and legal systems of other cultures (Yaşar Ekici, 2017), It can be said that pre-service teachers do not have enough formal and informal knowledge about other cultures.

According to the last finding reached in the study, the metacognition and motivation scores of the teacher candidates positively affect their cognitive flexibility levels. In other words, it can be said that individuals who show cognitive awareness (metacognition) about the cultural preferences of other people and have internal motivation and self-efficacy (motivation) in terms of having intercultural experiences and adapting to different cultural environments, have a high level of cognitive flexibility.

Cognitive flexibility and cultural intelligence variables discussed in this study are both frequently mentioned in the literature (Barak and Levenberg, 2016; Guzman, Durden, Taylor, Guzman, and Potthoff, 2016; Herrmann, 2015; SHRM Foundation, 2015; Willis, 2016) as $21^{\text {th }}$ century skills. Therefore, it is one of the main outputs expected to be produced by a qualified education system in the Industry 4.0 era. In pre-service training of teachers, it is an inevitable necessity for teacher candidates to acquire these skills. It can be said that course contents, teaching processes and methods should be reconsidered within the framework of this need. To give an example through two terms frequently used in media sociology, if these transformations are not realized in our education system, digital natives in the Industry 4.0 society will go far beyond the borders of digital immigrants and the teachers of the future will lose their role's in their classrooms to their students. 